\title{
Job Satisfaction as a Mediator between Transformational Leadership and Organizational Citizenship Behaviours
}

\author{
Abd Rahman Ahmad ${ }^{1}$, Alaa S. Jameel ${ }^{2}$ \\ ${ }^{I}$ Faculty of Technology Management and Business, Universiti Tun Hussein Onn \\ Malaysia, 86400 Batu Pahat, Johor, Malaysia, \\ ${ }^{2}$ Faculty of Technology Management and Business, Universiti Tun Hussein Onn \\ Malaysia, 86400 Batu Pahat, Johor, Malaysia, \\ Iarahman@uthm.edu.my, ${ }^{2}$ salam.alaa23@gmail.com
}

\begin{abstract}
Organizational Citizenship Behaviors (OCBs) involves voluntary activities which do not form part of the organizational roles of workers and do not explicitly take into account the formal organizational compensation structure even though they improve the organization's general efficiency. To create a safer working environment and enhance job efficiency, education institutions must embrace and promote the OCBs. When workforce demonstrates OCBs actions, and they will increase their level of engagement and improve the performance of institutions. Such organizations would now be able to fulfil their objectives and better serve society. The purpose of the study to examine the impact of Transformational Leadership (TL) on organizational citizenship behaviours (OCBs), as well as the mediating role of job satisfaction (JS) in the Iraqi primary schools. Data collected from 172 teachers in some selected schools in Al Anbar Governorate through questioners and the data analysed by Smart PLS 3.2.9. The results indicated that Transformational leadership impacted teachers OCBs positively. Furthermore, Job satisfaction positively impacted OCBs and mediated between TL and OCBs. Implications the study emphasizes the importance of teachers OCBs and recommends that schools should encourage their mangers and administrative to exhibit more TL (Motivational, stimulating and creative actions). This study demonstrates the degree to which the internal motives of Teachers, particularly their Job satisfaction, lead to extra roles and affect OCBs-leaders from developing country prospects.
\end{abstract}

Keywords: Transformational Leadership, organizational citizenship behaviour, Job satisfaction, School

\section{Introduction}

Organizational Citizenship Behaviors (OCBs) involves voluntary activities which do not form part of the organizational roles of workers and do not explicitly take into account the formal organizational compensation structure even though they improve the organization's general efficiency. However, OCBs considered as 'extra-role' activities, which are not part of subordinates requirements but enhance the productivity and performance of organizations altogether (Dartey-Baah \& Addo, 2019). (Bambale, Shamsudin, \& Subramaniam, 2011) indicated the management of employees with transformational leadership style (TL) and their effect on OCB's staff had earned more attention than the transactional leadership style. According to Bass (1985), this may be because, in empirical research, the transformational style has been shown to inspire workers to meet their minimum goals. Previous studies indicated to enhance OCBs among employees, and the organizations should encourage managers to be a more transformational leader. OCBs were extensively researched as a result of leadership styles, particularly TL (Aldrin \& Yunanto, 2019; Anggraini, Fahmy, Murni, \& Fatmadona, 2018; Nohe \& Hertel, 2017).

According to Nahum-Shani and Somech (2011), the impact of leadership on OCBs need more investigations and studies by researchers. Need more research conducting into 
how leadership impact on OCBs. Several studies have been undertaken and confirmed the effect of TL on OCBs (Anggraini et al., 2018; Krishnan \& Arora, 2008; Mekpor \& Dartey-Baah, 2017).on the other hand, TL did not impact on OCBs (Podsakoff, MacKenzie, Moorman, \& Fetter, 1990). In this mean, there is inconsistency in previous literature results. However, Several prior studies examined the direct impact of TL on OCBs (Ali, Ali, Ahsan, Rahman, \& Jan Kakakhel, 2014; Hassi, 2019; Krishnan \& Arora, 2008; Mekpor \& Dartey-Baah, 2017). Meanwhile, the direct impact may not enough explain the effects of TL on OCBs in changing environment nowadays. Our study will find the mediating role of Job satisfaction (JS) to test the causal effect between TL and OCBs and to fill this gap. However, a limited study conducted among schools (Ali et al., 2014; Nguni, Sleegers, \& Denessen, 2006), particularly in Iraqi setting which is suffering from lack of studies, conducted to examine the impact of TL on OCBs through JS.

Notwithstanding the perceived prediction of TL on JS, and the Find out the impact of JS on OCBs, Literature has a shortage of the conceivable mediating role of JS between TL and teachers' OCBs. At the same time, JS confirmed as a mediator between ethical leadership and OCBs (Ruiz-Palomino, Ruiz-Amaya, \& Knörr, 2011). As mentioned above the Iraqi context suffering from lack of studies, especially in the education system. Meanwhile, this system facing extensive criticism nowadays because of the low success rates among students. Iraq was own to have one of the best systems of education in the region. Still, decades of conflicts and three wars respectively Iraq -Iran war 1980-1988, gulf war 1990-1991, American occupation 2003 and recently the conflict against the Islamic State (IS) has a substantial negative impact on the education system in Iraq. One in two public schools needs rehabilitation, schools are overcrowded, and there is a shortage of teachers, particularly in conflict areas (UNICEF, 2019). Meanwhile, around 3.2 million Iraqi children aged school out of the school and $90 \%$ of school-age children have left the school in some governorates due to the conflicts and displace (UNICEF, 2018). Children out of schools are more vulnerable to violence and misconduct, including child labour, armed recruitment. Children and teachers have felt the traumas of violence, relocation and loss of loved ones. Such traumas have long term psychological effects that can impair educational processes and coping skills (Jameel, Mahmood, \& Jwmaa, 2020).

As a result, this study aimed to explore the impact of TL on OCBs via JS as a mediator in the Iraqi education sector. Additionally, enrich the body of knowledge in the Iraqi context among primary schools teachers.

\section{Literature review}

\subsection{Organizational Citizenship Behaviours}

Organ, (1988, p. 4) defined OCBs as 'individual behavior that is discretionary, not directly or explicitly recognized by the formal reward system, and that in the aggregate promotes the effective functioning of the organization'. OCBs helps businesses thrive and expedites creativity and new solutions in the unpredictable contemporary world. Institutions are encouraged to make every possible effort to create, maintain and sustain a favorable working atmosphere that promotes OCBs among their staff. To create a safer working environment and enhance job efficiency, education institutions must embrace and promote the OCBs. When workforce demonstrates OCBs actions, and they will increase their level of engagement and improve the performance of institutions. Such organizations would now be able to fulfil their objectives and better serve society (Ahmad \& Jameel, 2018) volunteer job necessary at any workplace. They could lead to enhance the performance of the organization. Additionally, the volunteer job could be achieved through OCBs. Absent the collective will to participate; organizations can not improve their effectiveness (Asgari, Mezginejad, \& Taherpour, 2019). Individuals with an OCBs act outside their duties and share their strength, ambition and perspective to succeed in the company's interests (Asgari et al., 2019). Most researchers agree that this factor is multidimensional, and a literature review indicates a lack of consensus on this aspect (Organ, 1988). OCBs consists of several dimensions which measure it. Altruism: actions 
aimed at helping to complete a mission or to fix a job problem, for example, helping a colleague with overloaded. Conscientiousness: While altruism targeted at the employee, conscientiousness, particularly devotion and loyalty to the organization aimed at the organization. Sportsmanship: refer to the organization as well, and describes cases in which an individual accepts unfavourable circumstances without any protest or criticism. Civic virtue: the concern of the individual for the institution and its successful activity. Courtesy: it is an Individual activity that includes co-operation and communication with co-workers on issues affecting the institution. According to Somech and Drach-Zahavy (2000) in the education setting, OCBs has three distinguished theories; First, refers to individual level, such as donation of actions and behaviours. Second, refers to team level, such as sharing of knowledge and Cooperative actions or behaviours Third, refers to Organization, such as Unpaid job volunteers for doing some task. OCBs has two main theories which consider as roots this factor it is The Social Exchange Theory and theory of Fairness and Social Justice. the social exchange emphasises the relationship between the individual and institutions or organization (Blau, 1964) as well the exchange consists of remuneration of the employee may refer to financial or non-financial (Economic exchange ) and the exchange emphasizes justice, trust in the manger or employer, integrity and commitment (social exchange) (Blau, 1964). social justice refers to the equity theory by (Adams, 1965)and the justice perception of the individual in the workplace lead to helping others. The individual usually compare what he or she received such as reword, promotion, salary with what others received in the same levels. The similar the rate of salary, promotion, reward, and for the employee to that of other employees, the more his or her sense of fairness (Karem, Mahmood, Jameel, \& Ahmad, 2019). Knowledge of an organization's unfairness prevents an individual from helping others thus the essential condition of OCBs to existence in the workplace is fairness among the individuals (Oplatka, 2006).

\subsection{Transformational Leadership and OCBs}

Transformation leadership style was chosen because of its quality, dedication, performance and innovativeness, which will be necessary for the education system. Transformational leadership aims at moving the institution and its employees from the present condition into a better state in alignment with the purpose and objectives of the organization. This mechanism involves several factors, such as organizational principles, organizational success expectations, long-term strategic objectives, ethical leadership and emotions of followers. Transformational leadership seeks to transform and encourage members priorities to achieve goals beyond their ability and aspirations (Jameel \& Ahmad, 2020). It is a close relationship between the leader and his followers that encourages him to look beyond the horizon while finding new directions to achieve the organization goals (Jameel \& Ahmad, 2019a).

Transformational leaders inspire followers to meet their work requirements by setting ambitious goals (Hassi, 2019; Al Hammadi, et. al., 2019). Burns, (1978) consider the first one who depicted the leadership as a transforming' (p. 4). according to the prior literature, transformational leadership could be the most effective method of leadership in this era (Bass, Avolio, Jung, \& Berson, 2003; Bass \& Riggio, 2006). According to Bass (1985) and Bass et al., (2003) TL consists of four main components: idealized influence, Leaders admired, valued and trusted by idealized influence and are expected to receive praise from subordinates and followers. Who can make their efforts to lead more efficient and efficient in increasing the faith of followers in their capacity and their growth. Inspirational motivation, mean the leaders who express their staff a compelling vision for the future demonstrate faith that the planned objectives will be reached, develop team morale and enthusiasm (Bass \& Riggio, 2005). intellectual stimulation, leaders encourage their members to develop their creative skills by empowering them to think for themselves, question assumptions, reframe problems and to encourage workers to take a new perspective when they face daily work tasks (Bass \& Riggio, 2005). individualized 
consideration involves leaders who serve as coaches or mentors to help their followers develop and reach their full potential by providing educational opportunities and a favourable climate (Bass \& Riggio, 2005). The literature almost agrees the TL enhance OCBs among the employees. Transformational leadership qualities will empower, inspire and promote OCBs among followers (Krishnan \& Arora, 2008). According to Purvanova, Bono, and Dzieweczynski (2006) TL change the way staff perceive about their job and make it more satisfying, challenging, and essential, which influences how much they participate in organizational citizenship. However, A great leader in an institution will be able to motivate staff to conduct with successful organizational outcomes and engage in organizational citizenship behaviours (Khalili, 2017). Transformational leaders are more likely to encourage their followers to display courteous and sports attitudes, such as the right of other people to share resources, the effect of their acts on others (MacKenzie, Podsakoff, \& Fetter, 1991).

Schools administrators, as a leader, play a significant part in making teachers feel like they are part of the workplace or the school and function more effectively within the school and enhance their OCBs. However, Schools leaders must be open to implementing transformational leadership and has ethically deal with teachers as well as respect the viewpoint of teachers (Oğuz, 2010). Nguni et al., (2006) indicated the level of OCBs would highly exist among the teachers when implementing the role of transformational leadership but not same with transactional leadership. Evidence from meta-analyses which is conducted by (Wang, Oh, Courtright, \& Colbert, 2011) indicated the TL able to explain and predict the OCBs more than other leadership styles.

According to Purvanova et al., (2006), TL has a positive impact on OCBs, and they reported the TL able to enhance and increase the OCBs among employees'. Likewise, a study conducted in the Middle East setting by (Khalili, 2017) and reported the TL has a significant impact on OCBs among employees. Additionally, in the study conducted by (Oğuz, 2010) in Turkey reported transformational leadership has a meaningful relationship with OCBs among teachers. A similar result was reported by (Nguni et al., 2006), which found the TL has a positive impact on OCBs in the school system. A study conducted in Pakistan by (Ali et al., 2014) among schools' teachers and reported the TL has a positive and significant impact on OCBs among teachers. Meta-analyses carried out by Wang et al., (2011) confirmed the impact of TL on OCBs. Other several studies confirmed TL has a positive and significant impact on OCBs (Anggraini et al., 2018; Hassi, 2019; Krishnan \& Arora, 2008; Mekpor \& Dartey-Baah, 2017)

\section{H1: TL has a positive and significant impact on Teachers OCBs. JS and OCBs}

JS is an essential topic for people working in organizations and for researchers as well. It's a vital subject in research on organizational behavior. Job satisfaction can be described briefly as a mixture of the positive or negative feelings workers have towards their work. (Locke, 1976) described it as "a pleasurable or positive emotional state resulting from the appraisal of one's job or job experiences" (p. 1304). An individual with work satisfaction has optimistic attitudes to the workplace while an unhappy individual has negative attitudes. JS is a collection of positive or negative emotions and feelings (Ahmad \& Jameel, 2018). Job satisfaction is expressed through the fulfilment of duties and refers to emotional and behavioural, physiological, and environmental conditions that lead a person to fulfil histher work (Hassi, 2019). However, Job satisfaction got several categorizations and facets by several researchers. One of the leading classification proposed by (Smith, Kendall, \& Hulin, 1969), JS consists of salary or pay, employees promotions, work environment and supervision.

Job satisfaction is expressed through the fulfilment of duties and refers to emotional and behavioural, physiological, and environmental conditions that lead a person to fulfil his work (Hassi, 2019). OCBs occurs in the workplace when individuals have a high level of satisfaction (Bateman \& Organ, 1983). according to Ahmad and Jameel (2018), 
the individuals with high job satisfaction have a higher OCBs degree. if job satisfaction exists in the workplace, it will enhance OCBs (Indarti, Solimun, Fernandes, \& Hakim, 2017). Job satisfaction profoundly impacts on OCBs among non-academic employees. Meanwhile, job satisfaction encourages OCBs among University employees (Wahyu, Tentama, \& Diah Sari, 2019). Meeting the needs of the employee, both job and interpersonal, would satisfy workers while employed and inspire them to make improvements, such as volunteer service which is part of OCBs (Wahyu et al., 2019).

An early study conducted by Bateman and Organ, (1983) reported JS has a direct impact on OCBs. However, a study conducted among teachers in Malaysia by (Tharikh, Ying, Mohamed Saad, \& Sukumaran, 2016) found JS has a positive and significant impact on OCBs among teachers. Other study conducted in education filed by (Indarti et $a l ., 2017)$ reported the OCBs influenced by JS among academic staff in Indonesia. JS has a positive impact on OCBs among primary school teachers in Tanzania (Nguni et al., 2006). As well in Pakistan (Ali et al., 2014).on the other hands, job satisfaction does not predict OCBs among secondary school teacher's in Pakistan (Awan, 2018).

\section{H2: JS has a positive and significant impact on Teachers OCBs. \\ TL and JS}

Although different leadership styles play various roles which could affect JS, the author primarily focuses on the role of TL. Ahmad and Jameel (2018) believe that workers perform at an acceptable level when they realize that their managers are transformational and are concerned about their well-being properly. A study conducted by (Fernandes \& Awamleh, 2004) revealed that the TL of managers enhances and increase JS in general and particularly in a multicultural environment. Transformational leadership plays a significant role in fostering individual satisfaction because change management allows its followers to meet stronger human desires. Considering that academic staff in the education sector are more likely to be driven internally, transformational leadership is essential to increased employee satisfaction within the education sector (Jameel \& Ahmad, 2019b). Burns (1978) developed the idea of TL based on the theory of a hierarchy of needs by Maslow in which esteem and self-realization are the essential human needs (Herzberg, 1966; Maslow, 1943). The theory can be applied directly to TL and employee satisfaction; because individuals can now meet their own higher expectations, useful TL will enhance job satisfaction as it increases organizational efficiency. Numbers of studies emphasize the impact of TL on JS and TL improve and expand the JS. The reason behind the findings is that individuals experience leadership actions and then respond to leadership and change their job satisfaction levels. An individual who has a healthy level of job satisfaction that makes his opinion of the manager and the manager more optimistic. (Jameel \& Ahmad, 2020)

Earlier research, conducted by (Hater \& Bass, 1988), showed that contingent rewards and TL were positively related to the satisfaction, performance and efficiency of the followers. As a result, the implementation of advanced TL practice criteria results in a high degree of supervisory satisfaction (Jameel \& Ahmad, 2019b). Based on the metaanalysis study conducted by (Judge \& Piccol, 2004) indicated employees' views of TL positive association to JS. However, other several studies confirmed TL has a positive and significant impact on JS (Aldrin \& Yunanto, 2019; Anggraini et al., 2018; Hassi, 2019). H3: TL has a positive and significant impact on JS among Teachers.

\section{The mediating effect of JS between TL and OCBs}

Finally, several studies deployed JS as a mediator between several factors. Recently, investigating JS as a mediator between Leadership styles and job performance at Iraqi public universities (Jameel \& Ahmad, 2020). Meanwhile, (Wahyu et al., 2019) reported the JS fully mediating the relationship between Organizational Climate and OCBs and partial mediating between the Servant Leadership and OCBs. JS has a fully mediating role between ethical leadership and OCBs (Ruiz-Palomino et al., 2011). job satisfaction 
mediates the impact of TL on OCBs among schools teachers (Nguni et al., 2006), Job satisfaction fully mediating between TL and OCBs and partial mediating between organizational culture on OCBs (Aldrin \& Yunanto, 2019). The studies mentioned above encouraged us to choose JS as a mediating between TL and OCBs in the context of Iraq.

H4: Job satisfaction mediates the relationship between TL and OCBs among Teachers.

\section{Methodology}

The sample size consisted of 172 teachers from 12 primary schools located in $\mathrm{Al}$ Anbar Governorate in the west of Iraq. The purpose behind choosing this location due to the population is high and education level as well the economic level of the residents. The study employed the stratified sample technic to collect the data from 12 primary schools during the academic year 2019-2020. The reason behind choosing the stratified sample is to ensure the equal distribution of a questionnaire to all the schools depending on the number of staff - the total teachers in these schools 506 teachers. According to (Krejcie \& Morgan, 1970) if the population around 506, the sample size is 207. However, out of 207 questionnaires were distributed only 184 questionnaires returned, and after data screening by checking outliers, missing value and incomplete questionnaires, the total valid to analysis only 172 questionnaires. Most of the responds were Male $62 \%$ while the Female $38 \%$. However, $82 \%$ with Bachelor qualifications and $11 \%$ and 7 holding Master and $\mathrm{PhD}$ respectively. The data was analyzed by using Smart-PLS 3.2.9.

\subsection{Instruments}

The items of questionnaires were adopted from prior studies by the English language and translated to the Arabic language accurately follow " back-translation process (Brislin, 1986). Additionally, the study employed five-point Likert scale 1- strongly disagree to 5-strongly agree. The sources and the number of items as follows:

1- OCBs 5 items adopted from (Podsakoff et al., 1990).

2- TL 5 Items adopted from the Multi-Factor Leadership Questionnaire by (Bass, 1985)

3- JS 5 items adopted from (Smith et al., 1969).

\section{Results}

The study employed Smart-PLS to data analysis, and according to Hair, Sarstedt, Hopkins, and Kuppelwieser (2014), two main steps should be achieved when Smart-PLS is implementing.

\subsection{Measurement model}

The purpose of this step is to assess the validity and reliability. The composite reliability (CR) of the constructs above the recommended level 0.70 (Hair et al., 2014) and showed high internal consistency range from 0.921 to 0.936. as well as Cronbach's Alpha results exceed 0.70. Next, the average variance extracted (AVE) of all the variables exceeded the recommended value 0.5, (Hair et al., 2014) range from 0.701 to 0.746 which indicate sufficient convergent validity see Table 1. Outer Loading (Factor loading) all items showed high loadings which are above-recommended level 0.70 (Hair et al., 2014) rang of loading between 0.747 and 0.918 . 
Table 1. Construct Reliability and Validity

\begin{tabular}{|c|c|c|c|c|}
\hline Factor & loading & CA & CR & (AVE) \\
\hline & 0.821 & & & \\
JS & 0.903 & & & \\
& 0.918 & 0.891 & 0.921 & 0.701 \\
& 0.785 & & & \\
& 0.747 & & & \\
& 0.801 & & & 0.724 \\
OCB & 0.879 & & & \\
& 0.907 & 0.904 & 0.929 & \\
& 0.875 & & & 0.746 \\
& 0.785 & & & \\
\hline & 0.859 & & & \\
& 0.896 & & & \\
& 0.897 & 0.915 & 0.936 & \\
\hline
\end{tabular}

Fornell-Larcker Criterion examined to measure the Discriminant validity, and the result indicated each item own with high correlation with itself and higher than other items. On other words, each item carrying more top square root of AVE to other items. Mean study own good discrimination validity (Fornell \& Larcker, 1981) see Table 2.

Table 2. Fornell-Larcker Criterion

\begin{tabular}{|l|l|l|l|}
\hline & JS & OCB & TL \\
\hline JS & $\mathbf{0 . 8 3 7}$ & & \\
\hline OCB & 0.527 & $\mathbf{0 . 8 5 1}$ & \\
\hline TL & 0.546 & 0.484 & $\mathbf{0 . 8 6 4}$ \\
\hline
\end{tabular}

\subsection{Structural model}

Considers the second step, which examined by bootstrapping function with 5000 subsamples (Hair et al., 2014) and $5 \%$ error and $95 \%$ confidence. The results indicated for the direct effect of the variables as depicted in Table 3. TL was positively and significantly impacted on OCBs among teachers due to the T-statistics $3.060>1.96$, Pvalue $<0.05$ and Beat 0.280 . Thus, $\mathrm{H} 1$ accepted. While JS has a positive and significant impact on OCBs T-statistics $4.372>1.96$ and P-value $<0.05$ and Beat 0.374 Thus, H2 accepted. Similarly, the $\mathrm{H} 3$ has been accepted, which is proposed to measure the impact of TL on OCBs among teachers T-statistics 8.677, P-value >0.05 and Beat 0.546.

Table 3. Path coefficient

\begin{tabular}{|l|c|c|c|}
\hline Hypotheses & Beta & T Statistics & P Values \\
\hline H1: TL -> OCB & 0.280 & 3.060 & 0.000 \\
\hline H2: JS -> OCB & 0.374 & 4.372 & 0.000 \\
\hline H3: TL -> JS & 0.546 & 8.677 & 0.002 \\
\hline \multicolumn{2}{|l|}{ Note: TL: transformational Leadership, JS: Job Satisfaction, OCBs: organizational citizenship behaviours }
\end{tabular}




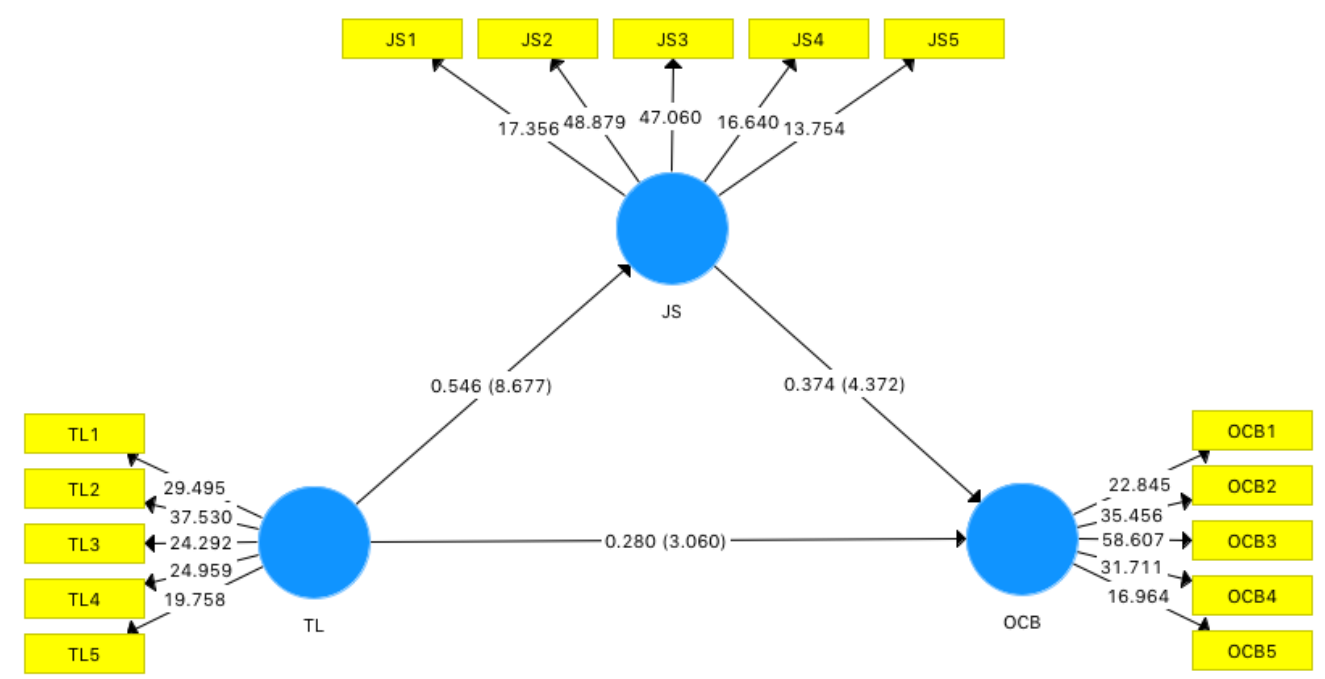

Figure 1. Path coefficient and t-value

\subsection{Mediation}

According to Preacher and Hayes (2008)To test the mediation, there are two main steps, first should ensure the significant direct impact of independent on dependent before entering the mediation. Second, should find the Confidence Interval of lower limit (LL) and, the upper limit (UL) at $95 \%$ confidence interval and the standard indicated the zero should not straddle between the variables, this step achieved (Table 4). The mediation analysis between TL and OCBs via JS investigated (Table 4) illustrates the result. The results indicated the direct impact of TL on OCBs without the mediator, was positive and significant (Beta 0.280 and P-value >0.05), Therefore, according to the results were the positive and significant impact of TL on OCBs when mediating for JS occur (Beta 0.204 and p-value > 0.05). Though the mediating, when considered the beta decreased if compared with the direct impact form 0.280 to 0.204 , this means the partial mediation exist between TL and OCBs via JS; thus, Hypothesis 4 accepted.

Table 4. Mediation analysis

\begin{tabular}{|l|l|l|l|l|l|}
\hline & Beta & T Statistics & P Values & LL & UL \\
\hline H4 TL -> JS -> OCB & 0.204 & 4.127 & 0.000 & .108 & .300 \\
\hline
\end{tabular}

\section{Discussion}

The primary purpose of this study is to examine the mediating role of JS between TL and OCBs among primary schools teachers in Iraq. Thus this purpose has been achieved. TL has a positive and significant impact on OCBs among Iraqi teachers several prior findings support this result (Anggraini et al., 2018; Hassi, 2019; Krishnan \& Arora, 2008; Mekpor \& Dartey-Baah, 2017). Relating to supplying the program with innovative ideas, building an atmosphere favourable to the schools in the external world, self-training and collaboration with fellow staff. This is inevitable that School administrators have a significant role to play in making professors believe they are part of the school. It is also crucial that school administrators are straightforward and open to change, and can make ethical decisions and respect and understand teacher beliefs. Transformation leaders (School administrators) strive to inspire their followers (teachers) to meet their 
expectations, such as, adopt behaviours and conduct that go beyond individual desires and give priority to common causes. It can, therefore, be understood that such leadership has been a good indicator of an action to build a system-friendly environment as this kind of conduct helps the school collectively. Transformation leaders are given the flexibility to their followers and empower them to deal with problems to enhance output and productivity. The teachers will, therefore, be expected to exhibit a higher propensity to give innovative suggestions to the program and the education system, as they feel more autonomous and confident in offering solutions which will help them cope with problems and improve their efficiency. Transformational leaders (School administrators) strive to adopt behaviours designed to incorporate, organize and promote their teachers 'efforts. Thus, they play a central role in developing a schools environment.

Job satisfaction has a positive and significant impact on OCBs. This result in line with previous findings (Ali et al., 2014; Indarti et al., 2017; Nguni et al., 2006).Thus, This suggests that enhanced attitude, organizational engagement and satisfaction would contribute to better OCBs among Iraqi teachers. The more cooperative teachers viewed the actions of their school administrators, the more likely they would involve in the OCBs, such as making recommendations on change, attending meetings willingly or assisting colleagues with work. TL has a positive impact on teachers JS this result consistent with the previous literature (Aldrin \& Yunanto, 2019; Anggraini et al., 2018; Hassi, 2019; Ghran, et. al., 2020).TL lead to staff engaging in institutional decisionmaking processes, maintaining open contact networks with workers, etc. improves employee satisfaction, encourages the association of employees with the workplace and its priorities and enhances their ability to practice OCBs. In particular, teachers 'affiliation with and dedication to school are of vital significance for educational institutions, since they affect the relationship with the school administrators as well as the whole workplace.

JS has a significant mediating between TL and OCBs among Iraqi teachers. Although several studies conducted among schools teachers have investigated the direct impact and direct relationship between TL and the OCBs without mediating (Ali et al., 2014; Awan, 2018; Oğuz, 2010; Tharikh et al., 2016). This could be a gap, and this study examined the JS as a mediating between TL and OCBs to fill the gap, particularly in the Iraqi setting. The result of this study indicated JS indeed play a mediator role between TL and OCBs among teachers. The result of JS as a mediator in line with previous literature (Aldrin \& Yunanto, 2019; Nguni et al., 2006; Wahyu et al., 2019). Iraqi public schools should give more attention to TL as well as JS to create or enhance the OCBs among Iraqi teachers. Our findings thus endorse the theory of social exchange and stress the importance of reciprocal dependency on social exchange. This kind of interaction between the school administrators and the teacher encourages teachers to engage in their jobs and help to fulfil the demands of the schools outside their formal position and thus to display a high degree of OCBs.

\section{Conclusion}

Based on the results of this study, there is a direct positive and significant impact of TL and JS on OCBs among teachers. The better TL and JS in schools will enhance and increase the OCBs among teachers. However, the mediating role of job satisfaction existed between TL and OCBs, which is mean the higher TL will lead to high OCBs and if mediated, JS is also higher. Our study reveals the critical role of school administrators in supporting OCBs among teachers, and the value of OCBs in the development of schools, encouraging high-quality education for Iraqi school. The human capital is the most significant aspect that can make a difference. Teachers OCBs consider one of the critical resources necessary for introducing changes despite, the education system in Iraq suffers from a range of unique deficiency in the form of continuing cuts in the Budget due to the security issues and the economic situation recent years, and at the same time, the vulnerability of the entire Iraqi education system. Implications of this study emphasize the importance of teachers OCBs and recommend that schools should encourage their 
mangers and administrative to exhibit more TL (Motivational, stimulating and creative actions). This study demonstrates the degree to which the internal motives of Teachers, particularly their Job satisfaction, lead to extra roles and affect OCBs-leaders from developing country prospects as well in Iraq.

\section{Acknowledgment}

The authors would like to thank you to Research Management Office (RMC), Universiti Tun Hussein Onn Malaysia for allowed this paper to be presented by covering fees by using research fund (E15501) UTHM.

\section{References}

[1] Adams, J. S. (1965). Inequity In Social Exchange. Advances in Experimental Social Psychology. https://doi.org/10.1016/S0065-2601(08)60108-2

[2] Ahmad, M. A.-A., \& Jameel, A. S. (2018). Factors Affecting on Job Satisfaction among Academic Staff. Polytechnic Journal, 8(2), 119-128. https://doi.org/https://doi.org/10.25156/ptj.2018.8.2.161

[3] Aldrin, N., \& Yunanto, K. T. (2019). Job Satisfaction as a Mediator for the Influence of Transformational Leadership and Organizational Culture on Organizational Citizenship Behavior. The Open Psychology Journal, 12(1), 126-134. https://doi.org/10.2174/1874350101912010126

[4] Ali, N., Ali, S., Ahsan, A., Rahman, W., \& Jan Kakakhel, S. (2014). Effects of leadership styles on job satisfaction, organizational citizenship behavior, commitment and turnover intention (empirical study of private sector schools' teachers). Life Science Journal, 11(SPEC. ISSUE 3), 175-183.

[5] Al Hammadi, A. H. Y., Ahmad, A. R., Al Hammadi, A. H. Y., \& Isa, K. (2019). The influence of leadership styles on organisation performance. Paper presented at the Proceedings of the 33rd International Business Information Management Association Conference, IBIMA 2019: Education Excellence and Innovation Management through Vision 2020, 6167-6170

[6] Anggraini, S. S., Fahmy, R., Murni, D., \& Fatmadona, R. (2018). The effect of transformational leadership and organizational climate with satisfaction partnership at hospital RSUD Pariaman Indonesia in 2017. Indian Journal of Public Health Research and Development, 9(11), 447-451. https://doi.org/10.5958/09765506.2018.01496.1

[7] Asgari, A., Mezginejad, S., \& Taherpour, F. (2019). The role of leadership styles in organizational citizenship behavior through the mediation of perceived organizational support and job satisfaction. Innovar, 30(75), 8798. https://doi.org/10.15446/innovar.v30n75.83259

[8] Awan, R. (2018). The Moderating Role of Gender in the Relationship among Organizational Justice , Commitment, Job Satisfaction and Organizational Citizenship Behaviors of Secondary School Teachers. Pakistan Journal of Education, 35(1), 97-112.

[9] Bambale, A. J., Shamsudin, F. M., \& Subramaniam, C. A. (2011). Stimulating organizational citizenship behavior (OCB) research for theory development: Exploration of leadership paradigms. International Journal of Academic Research in Business and Social Sciences, 1(Special Issue), 48-69.

[10] Bass, B. M. (1985). Leadership and Performance Beyond Expectations. https://doi.org/10.5465/amr.1987.4306754

[11] Bass, B. M., Avolio, B. J., Jung, D. I., \& Berson, Y. (2003). Predicting unit performance by assessing transformational and transactional leadership. Journal of Applied Psychology. https://doi.org/10.1037/00219010.88.2.207

[12] Bass, B. M., \& Riggio, R. E. (2005). Transformational leadership: Second edition. In Transformational Leadership: Second Edition. https://doi.org/10.4324/9781410617095

[13] Bass, B. M., \& Riggio, R. E. (2006). Transformational leadership (2nd editio). Mahwah, NJ: Lawrence Erlbaum.

[14] Bateman, T. S., \& Organ, D. W. (1983). Job Satisfaction and the Good Soldier: The Relationship Between Affect and Employee "Citizenship". Academy of Management Journal. https://doi.org/10.2307/255908

[15] Blau, P. (1964). Exchange and power in social life. New York, NY: Wiley.

[16] Brislin, R. W. (1986). The wording and translation of research instruments. In Field methods in cross-cultural research .

[17] Burns, J. M. (1978). Leadership. https://doi.org/10.1007/978-4-431-09429-6_20

[18] Dartey-Baah, K., \& Addo, S. A. (2019). Psychological identification with job: a leadership-OCB mediator. International Journal of Organizational Analysis, 27(3), 548-565. https://doi.org/10.1108/IJOA-10-20171262

[19] Fernandes, C., \& Awamleh, R. (2004). And Transactional Leadership Styles On Employee 's Satisfaction And Performance : An Empirical Test In. International Business \& Economics Research Journal, 3(8), 65-76. https://doi.org/10.19030/iber.v3i8.3715

[20] Fornell, C., \& Larcker, D. F. (1981). Evaluating Structural Equation Models with Unobservable Variables and Measurement Error. Journal of Marketing Research, 18(1), 39. https://doi.org/10.2307/3151312

[21] Ghran, L. A. Z., Jameel, A. S., \& Ahmad, A. R. (2020). The effect of organizational justice on job satisfaction among secondary school teachers. International Journal of Psychosocial Rehabilitation, 24(3), 1302-1310. 
doi:10.37200/IJPR/V24I3/PR200880

[22] Hair, J. F., Sarstedt, M., Hopkins, L., \& Kuppelwieser, V. G. (2014). Partial least squares structural equation modeling with R. Practical Assessment, Research and Evaluation, 21(1), 1-16. https://doi.org/10.1108/ebr10-2013-0128

[23] Hassi, A. (2019). "You get what you appreciate": Effects of leadership on job satisfaction, affective commitment and organisational citizenship behaviour. International Journal of Organizational Analysis, 27(3), 786-811. https://doi.org/10.1108/IJOA-08-2018-1506

[24] Hater, J. J., \& Bass, B. M. (1988). Superiors' Evaluations and Subordinates' Perceptions of Transformational and Transactional Leadership. Journal of Applied Psychology. https://doi.org/10.1037/0021-9010.73.4.695

[25] Herzberg, F. (1966). Work of the Nature of Man. In The World of Publishing Company. Oxford, England: World.

[26] Indarti, S., Solimun, Fernandes, A. A. R., \& Hakim, W. (2017). The effect of OCB in relationship between personality, organizational commitment and job satisfaction on performance. Journal of Management Development, 36(10), 1283-1293. https://doi.org/10.1108/JMD-11-2016-0250

[27] Jameel, A. S., \& Ahmad, A. R. (2019a). Leadership and Performance of Academic Staff in Developing Countries. The 33rd International Business Information Management Association Conference, 6101-6106. Granada, Spain: IBIMA.

[28] Jameel, A. S., \& Ahmad, A. R. (2019b). The effect of Transformational Leadership on Job Satisfaction among Academic Staff. In The 34th International Business Information Management Association (IBIMA) Conference: 13-14 November 2019, Madrid, Spain.

[29] Jameel, A. S., \& Ahmad, A. R. (2020). The Mediating Role of Job Satisfaction between Leadership Style and Performance of Academic Staff. International Journal of Psychosocial Rehabilitation, 24(04), 2399-2414. https://doi.org/10.37200/IJPR/V24I4/PR201349

[30] Jameel, A. S., Mahmood, Y. N., \& Jwmaa, S. J. (2020). Organizational Justice and Organizational Commitment among Secondary School teachers. Cihan University-Erbil Journal of Humanities and Social Sciences, 4(1), 1-6. https://doi.org/10.24086/cuejhss.vol4n1y2020.pp1-7

[31] Judge, T. A., \& Piccol, R. F. (2004). Transformational and transactional leadership: A meta-analytic test of their relative validity. Journal of Applied Psychology, 89(5), 755-768. https://doi.org/10.1037/00219010.89.5.755

[32] Karem, M. A., Mahmood, Y. N., Jameel, A. S., \& Ahmad, A. R. (2019). The Effect of Job Satisfaction and Organizational Commitment on Nurses' Performance. Humanities and Social Sciences Reviews, 7(6), 332339. https://doi.org/10.18510/hssr.2019.7658

[33] Khalili, A. (2017). Transformational leadership and organizational citizenship behavior: The moderating role of emotional intelligence. Leadership and Organization Development Journal, 38(7), 1004-1015. https://doi.org/10.1108/LODJ-11-2016-0269

[34] Krejcie, R. V., \& Morgan, D. W. (1970). KrejcieandMorgan_article.pdf.

[35] Krishnan, V. R., \& Arora, P. (2008). Determinants of Transformational Leadership and Organizational Citizenship Behavior. Asia Pacific Business Review, 4(1), $34-43$. https://doi.org/10.1177/097324700800400104

[36] Locke, E. A. (1976). The nature and causes of job satisfaction. In Handbook of Industrial and Organizational Psychology.

[37] MacKenzie, S. B., Podsakoff, P. M., \& Fetter, R. (1991). Organizational citizenship behavior and objective productivity as determinants of managerial evaluations of salespersons' performance. Organizational Behavior and Human Decision Processes, 50(1), 123-150. https://doi.org/10.1016/0749-5978(91)90037-T

[38] Maslow, A. H. (1943). A theory of human motivation. Psychological Review, 50(4). https://doi.org/10.1037/h0054346

[39] Mekpor, B., \& Dartey-Baah, K. (2017). Leadership styles and employees' voluntary work behaviors in the Ghanaian banking sector. Leadership and Organization Development Journal, 38(1), 74-88. https://doi.org/10.1108/LODJ-09-2015-0207

[40] Nahum-Shani, I., \& Somech, A. (2011). Leadership, OCB and Individual Differences: Idiocentrism and Allocentrism as Moderators of the Relationship between Transformational and Transactional Leadership and OCB. The Leadership Quarterly, 22(2). https://doi.org/10.1016/j.physbeh.2017.03.040

[41] Nguni, S., Sleegers, P., \& Denessen, E. (2006). Transformational and transactional leadership effects on teachers' job satisfaction, organizational commitment, and organizational citizenship behavior in primary schools: The Tanzanian case. School Effectiveness and School Improvement, 17(2), 145-177. https://doi.org/10.1080/09243450600565746

[42] Nohe, C., \& Hertel, G. (2017). Transformational Leadership and Organizational Citizenship Behavior: A Meta-Analytic Test of Underlying Mechanisms. Frontiers in Psychology, 8(AUG), 1-13. https://doi.org/10.3389/fpsyg.2017.01364

[43] Oğuz, E. (2010). The relationship between the leadership styles of the school administrators and the organizational citizenship behaviours of teachers. Procedia - Social and Behavioral Sciences, 9, 1188-1193. https://doi.org/10.1016/j.sbspro.2010.12.305

[44] Oplatka, I. (2006). Going beyond role expectations: Toward an understanding of the determinants and components of teacher organizational citizenship behavior. Educational Administration Quarterly, 42(3), 385-423. https://doi.org/10.1177/0013161X05285987

[45] Organ, D. W. (1988). A Restatement of the Satisfaction-Performance Hypothesis. Journal of Management, 
14(4), 547-557. https://doi.org/10.1177/014920638801400405

[46] Podsakoff, MacKenzie, Moorman, \& Fetter. (1990). Transformational leadership behaviours and their effects on followers' trust in leader, satisfaction and organisational citizenship behaviours. The Leadership Quarterly, l(2), 107-142.

[47] Preacher, K. J., \& Hayes, A. F. (2008). Asymptotic and resampling strategies for assessing and comparing indirect effects in multiple mediator models. Behavior Research Methods, 40(3), 879-891. https://doi.org/10.3758/BRM.40.3.879

[48] Purvanova, R. K., Bono, J. E., \& Dzieweczynski, J. (2006). Transformational Leadership, Job Characteristics, and Organizational Citizenship Performance Radostina. Human Performance, 9(1), 1-22. https://doi.org/10.1207/s15327043hup1901

[49] Ruiz-Palomino, P., Ruiz-Amaya, C., \& Knörr, H. (2011). Employee organizational citizenship behaviour: The direct and indirect impact of ethical leadership. Canadian Journal of Administrative Sciences, 28(3), 244-258. https://doi.org/10.1002/CJAS.221

[50] Smith, P. C., Kendall, L. M., \& Hulin, C. L. (1969). The Measurement of Satisfaction in Work and Retirement: a Strategy for the Study of Attitudes. In Rand McNally Psychology Series.

[51] Somech, A., \& Drach-Zahavy, A. (2000). Understanding extra-role behavior in schools: The relationships between job satisfaction, sense of efficacy, and teachers' extra-role behavior. Teaching and Teacher Education, 16(5), 649-659. https://doi.org/10.1016/S0742-051X(00)00012-3

[52] Tharikh, S. M., Ying, C. Y., Mohamed Saad, Z., \& Sukumaran, K. a/p. (2016). Managing Job Attitudes: The Roles of Job Satisfaction and Organizational Commitment on Organizational Citizenship Behaviors. Procedia Economics and Finance, 35, 604-611. https://doi.org/10.1016/s2212-5671(16)00074-5

[53] UNICEF. (2018). Education Every child in school, and learning.

[54] UNICEF. (2019). Parents and Teachers Can Save Iraq's Ailing Education System, So Let Them Education system in Iraq.

[55] Wahyu, A., Tentama, F., \& Diah Sari, E. Y. (2019). The role of servant leadership and organizational climate on organizational citizenship behavior with job satisfaction as mediator. International Journal of Scientific and Technology Research, 8(10), 1134-1141.

[56] Wang, G., Oh, I. S., Courtright, S. H., \& Colbert, A. E. (2011). Transformational leadership and performance across criteria and levels: A meta-analytic review of 25 years of research. Group and Organization Management, 36(2), 223-270. https://doi.org/10.1177/1059601111401017

\section{Authors}

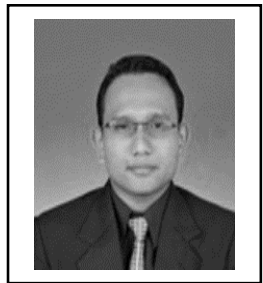

Abd Rahman Ahmad, Faculty of Technology Management and Business, Universiti Tun Hussein Onn Malaysia, 86400 Batu Pahat, Johor, Malaysia, 